\title{
The Analysis of Cognitive Moral in Bridging the Gap Between Internal Marketing and $\mathrm{B}_{2} \mathrm{~B}$ Salespeople Performance
}

\author{
Ribhan \\ Department of Management, \\ Faculty of Economics and Business, Lampung University, \\ Jl. Prof. Dr. Sumantri Brojonegoro 1, Bandar Lampung, \\ Lampung 35141, Indonesia

\section{Albet Maydiantoro} \\ Department Economic Education, \\ Faculty of Teacher Training and Education, Lampung University, \\ Jl. Prof. Dr. Sumantri Brojonegoro 1, Bandar Lampung, \\ Lampung 35141, Indonesia
}

DOI: https://doi.org/10.36941/ajis-2021-012o

\section{Abstract}

This study seeks to confirm and analyse the effect of cross-level cognitive morals on internal marketing and business sales force performance (i.e. behavioural performance and outcome performance). The concepts of relationship marketing and marketing theory of ethics underpin the relationship among variables. This study adopted a quantitative approach through a survey of 460 respondents from 13 company services and manufacturers. Internal marketing variables were measured at the unit level and tested using interrater agreement and the intraclass correlation. In contrast, the cognitive moral variables, behavioural performance, and sales force performance results were measured individually. Hierarchical linear modelling (HLM) was used to test the effect of the cross-level research variables. The results showed that internal marketing empirically supports cognitive morals. However, the effect of internal marketing does not support the two-dimensional performances of the sales force. Theoretically, the contributions, internal marketing and cognitive morals have shown the relationship between marketing and marketing theory of ethics.

Keywords: internal marketing, cognitive moral, performance behaviour, the results performance

\section{Introduction}

Internal marketing emphasises a process in which both internal customers (such as employees) and external customers (consumers) should have responsibility for the desired result (Manville \& Ober, 2003). Internal marketing is a process to create an environment that enables every employee to act both as a client and a customer to show responsibility (Novatorov, Kim, Wall, \& Crompton, 1998). The customer needs and desires must be understood from human resource management and marketing perspectives (Iacobucci \& Nordheilm, 2000). Furthermore, (George, 1990) emphasises that a blend of marketing and human resource management can explain internal marketing as a new 
perspective on its human resources management.

Some authors have attempted to integrate the role of human resource management and marketing in describing internal marketing by focusing employees or human resources as internal customers within the organisation (Bowen \& Lawler, 1992; Collins \& Payne, 1991; El Fawal, Berg, Wheatley, \& Harland, 1987; MacStravic, 1985; Varey, 1995; Winter, 1985). The term internal marketing, initially used by Berry (1981), is defined as a marketing process with a view of the employee considered an internal customer and working as an internal product that meets their needs and desires. Meanwhile, according to (Vasconcelos, 2008), the importance of internal marketing is to keep internal customers doing the same as external customers do in maintaining business performance. Therefore, the internal marketing concept appears to be the most appropriate managerial mechanism for putting the people in the right place and developing a job as a product in a broader perspective by changing organisation members' mind-set.

Internal marketing is a relationship marketing technique that should be taken into account when creating a plan to build long-term customer relationships (Berry, 2002; Husnain \& Akhtar, 2016). Furthermore, Berry argues that it is relevant to almost all organisations. The definition implies that internal marketing is a long-term exchange relationship between employees and leaders in organisations. According to the principle of relationship marketing, customers (employees) have long-term importance (Berry, 1981; Morgan \& Hunt, 1994). Parasuraman, Berry, \& Zeithmal (1991) suggest that one of the components of relationship marketing is trust, an essential element for a longterm relationship between the organisation and internal customers. A relationship should be based on the belief that contains ethical elements (Murphy, Laczniak, \& Wood, 2007). In the process, decision-making internal marketing also means creating ethical values or cognitive moral between the parties within the organisation. The ethical decision-making process is developed from cognitive moral influence on organisational performance (Schwepker \& Good, 2010). Each individual's role of values or moral values is recognised to have a strong influence on the company's performance and play an important role in many marketing environments.

Internal marketing as business performance facilitates the spread of ethical values and morals, which impacts eliminating immoral decision-making (Ahmed, Rafiq, \& Saad, 2003; Hunt \& Vitell, 2006). However, little is known about the interaction between cognitive moral variables and internal markets. Therefore, this study examines the effect of internal marketing and cognitive moral performance of employees who conduct business to business $\left(\mathrm{B}_{2} \mathrm{~B}\right)$ activities. $\mathrm{B} 2 \mathrm{~B}$ activities oriented towards a long-term relationship emphasise ethical behaviour. The $\mathrm{B}_{2} \mathrm{~B}$ marketing activities in business characterise the long-term commercial relationship between two organisations. Therefore, the company needs to pay attention to maintaining and preserving salespeople's ability as corporate assets. Salespeople in $\mathrm{B}_{2} \mathrm{~B}$ are customer-oriented (groups in organisations that have to manage the product or service in a relatively large amount) to increase future sales and commercial relationships.

Some research in internal marketing ignores the issue on the level of analysis. The construct of internal marketing in earlier studies is still focused on the organisation as a level of analysis. In their study, Van Bruggen, Lilien, \& Kacker (2002) found that many marketing organisations ignored the importance of the specific measurement model as the level of conceptualisation of the construct at the level of individual group or organisation. Previous marketing studies (Ahmed et al., 2003; Bouranta, Mavridoglou, \& Kyriazopoulos, 2005; Chi, Yeh, \& Chiou, 2008; Ha, Bakar, \& Jaafar, 2007; Hwang \& Chi, 2005; Keller, Lynch, Ellinger, Ozment, \& Calantone, 2006; Panigyrakis \& Theodoridis, 2009; Shiu \& Yu, 2010; Zaman, Javaid, Arshad, \& Bibi, 2012) have not clearly explained the measurement model specifications used to treat the construct.

Therefore, this study has two research gaps. First, this study methodologically and empirically examines the effect of cross-level internal marketing on cognitive moral and salespeople performance. Second, this study discusses a relationship between marketing strategy that contains a moral element to build and shape moral cognitive of the salespeople in making their decision to perform better.

This research tests the cross-level traffic effect of internal marketing on cognitive moral and 
multidimensional salespeople performance. It is important to be studied because the cross-level analysis can provide approaches and better conclusions to address the issues. The research is also aimed at integrating micro and macro components in a common framework, such as the effect of internal marketing on an organisational variable unit level on cognitive moral and salespeople performance (Mossholder \& Bedeian, 1983; Otaye-Ebede, Shaffakat, \& Foster, 2020).

\section{Literature Review}

Internal marketing focuses on creating a successful internal exchange between a company and a group of workers as a precondition for a successful external exchange. As the fundamental concept of internal marketing, this will improve the efficacy and efficiency of internal marketing programs (Aceleanu, Molănescu, Crăciun, \& Voicu, 2015; George, 1990; Gronroos, 1996). Internal marketing, as a relationship marketing technique, must be addressed when designing a long-term strategy for maintaining consumer relationships (Berry, 2002). Internal marketing is the practice of treating workers as internal consumers to develop individual values within the company, meet their needs and expectations, and eventually improve employee performance to achieve organisational objectives.

Internal marketing is a technique that seeks to build high-performance individual values of air by considering metrics such as the compensation system, internal communication, training and growth, and senior leadership support to promote higher employee performance, which in turn affects business performance (Ahmed et al., 2003; Jacobs, Yu, \& Chavez, 2016). Individual values are intended to be created by a symbiotic relationship between the company and internal consumers, resulting in improved profitability, customer satisfaction, market share, and organisational efficiency (Mazvancheryl, Anderson, \& Fornell, 2004). When a company can fulfil the needs and wishes of its workers while still providing resources, it becomes more accountable and oriented on achieving performance goals (Gummesson, 1987; Keller et al., 2006).

$\mathbf{H}_{\mathbf{1}}$ : Internal marketing has a positive effect on sales performance behaviour.

$\mathbf{H}_{\mathbf{2}}$ : Internal marketing has a positive effect on salespeople performance.

Moral considerations (i.e. the decision to behave correctly or incorrectly), moral values (i.e. the individual's beliefs about the value and action that is right or wrong), the development of cognitive moral (i.e. development of moral reasoning) will affect people in decision making such as marketing performance (Goolsby \& Hunt, 1992; Latif, 2000; Schwepker \& Good, 2010; Schwepker, 1999; Selvarajan \& Cloninger, 2009). Therefore, cognitive moral development can determine the professional success of marketing and salespeople to achieve the organisation's performance and success. The salespeople's role at the forefront of business organisations is implementing strategies designed to encourage and support long-term relationships with customers (Panagopoulos, Rapp, \& Ogilvie, 2017; Webster, 1992). They are required to initiate, establish, and maintain a lasting relationship. An increase in the development of a long-term relationship demonstrates the importance of the placement of ethical behaviour (moral behaviour) (Gundlach \& Murphy, 1993; Tran, Vo, \& Dinh, 2020).

Marketing activities are particularly vulnerable to ethical and moral decision-making. Ethical decisions in marketing are determined by individuals' moral considerations to achieve goals and perform better (Paais \& Pattiruhu, 2020; Sherwin, 1983). Therefore, an individual cognitive moral can determine the selection of individuals' decisions alternatives, especially salespeople, in achieving their performance, such as performance and performance behaviour.

$\mathbf{H}_{3}$ : Cognitive moral has a positive effect on salespeople's performance behaviour.

$\mathbf{H}_{4}$ : Cognitive moral has a positive effect on salespeople's results performance.

The salespeople's performance behaviour is an important dimension that relates directly to sales performance. Salespeople usually spend a lot of time on activities related to the sales results (Cravens, LaForge, \& Clifford, 1993). Performance behaviour refers to the activity and strategy of salespeople in implementing the sales process, while the results performance is the quantitative results obtained 
from the salespeople effort (Austin \& Villanova, 1992; Gomez-Mejia, Balkin, \& Cardy, 2007; Miao \& Evans, 2007; Varela \& Landis, 2010; Wall et al., 2004). Some studies show a positive causal relationship between performance behaviour and performance sales results (Cravens et al., 1993; Jaworski \& Kohli, 1991). The performance will predict behaviour and direct the salespeople results performance. If the salespeople have good performance behaviour and ethics, it will improve their results. Behaviours such as convincing the customer, understanding customer needs, and customer presentations correctly and adequately will determine the sales outcome or sales performance.

$\mathbf{H}_{5}$ : Performance behaviour has a positive effect on the performance results of salespeople.

Internal marketing is a process of creating an organisational environment in which every member of the organisation acts both as employees and customers to show responsibility (Novatorov et al., 1998; Zahari, Esa, Rajadurai, Azizan, \& Tamyez, 2020). For these purposes, a company should value and support its employees as internal customers, as well as build positive social relationships with both internal and external customers (consumers), in order to satisfy their needs and expectations, since employees have a responsibility to perform work (product) and deliver a performance (Ha et al., 2007; Hwang \& Chi, 2005; Jou, Chou, \& Fu, 2008; Keller et al., 2006). Customers have a long-term value, according to relationship marketing, as long as they do business with the brand (Berry, 2002; Morgan \& Hunt, 1994). Furthermore, Parasuraman et al. (1991) suggest that one of the relationship marketing components is trust which is a crucial thing to maintain a long-term relationship between organisations, internal customers, and external customers. This, of course, requires the company to provide the best service to the internal members (employees) before the external members. Companies should meet their employees' expectations because satisfied employees will be happy to do their job properly and correctly (Murphy et al., 2007; Neves, Almeida, \& Velez, 2018). Trust is the essence of relationship marketing ethics. Internal marketing geared to establish and maintain long-term relationships that are responsible for internal customers with the organisation in the ethical and moral issues, ethical and moral aspects of the assessment are at the heart of the most ethical decision-making model in the field of marketing, including sales personnel as one of the important factors in building a relationship with internal and external customers. Model HV (Hunt-Vitell Theory) proposes that the assessment of ethical and moral intention must be a better predictor of behaviour in situations where ethical issues are significant, such as individual performance. Hunt (2019); Jones (1991) use the HV theory as a theoretical foundation that focuses on the importance of the intensity of the moral and ethical issues as the key to understanding the situations that involve the content of ethical decision-making individual. The importance of internal marketing activities such as reward systems, training and development, leadership support and internal communication is directed to develop the values and norms of the salespeople in decisionmaking.

$\mathbf{H}_{6}$ : Internal marketing has a positive effect on moral cognitive

The six hypotheses tested in this study are illustrated in Figure 1 below.

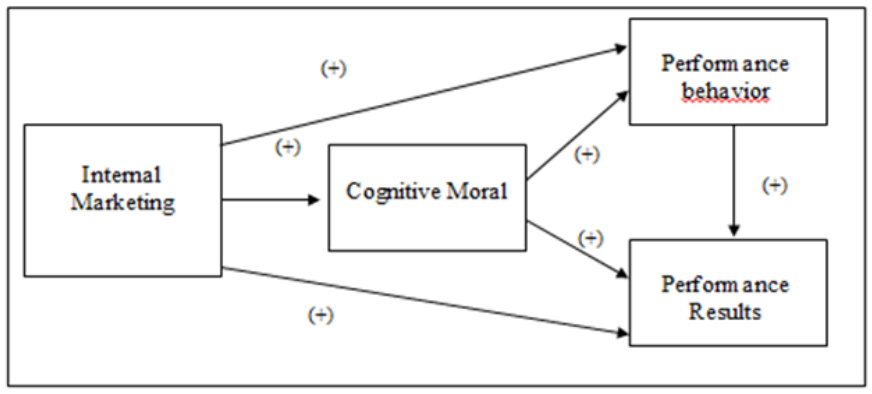

Figure 1: Research hypotheses testing 


\section{Methodology}

This research adopted a survey research design with a questionnaire as an instrument. Seven hundred eighty questionnaires were distributed, but only 565 (72.43\%) were returned. After an initial analysis, 105 of them were considered invalid. Therefore, 460 questionnaires were deemed to be valid for data analyses.

\subsection{Variable measurement}

Internal marketing was assessed using a tool devised by a group of researchers (Bennett \& Barkensjo, 2005; Bouranta et al., 2005; Caruana \& PCalleya, 1998; Ewing, 1999; Money \& Foreman, 1996; Naude, Desai, \& Murphy, 2003; Shiu \& Yu, 2010) with a total of 15 statements. Each statement was measured using a five-point Likert scale ranging from 1 (strongly disagree) to 5 (strongly agree).

For the measurement of cognitive moral salespeople (Ishida, 2006; Reidenbach \& Robin, 1988; Reidenbach, Robin, \& Dawson, 1991; Schwepker \& Good, 2010), respondents were asked to respond to three different scenarios with eight semantic statements on a scale of five points with adjective bipolar (fair/not fair, appropriate/inappropriate, morally justified/immorally justified).

The Sales Performance Result was measured by using a self-reported questionnaire developed by Behrman \& P Jr (1982); Schwepker \& Good (2010); Sujan, Weitz, \& Kumar (1994). The questionnaire was subjective, in which the respondents were asked to fill out the questionnaire based on the results of their work.

Furthermore, to measure the performance behaviour, an instrument developed by Jaworski \& Kohli (1991); Schwepker \& Good (2010); Sujan et al. (1994) was used to measure using a 5-point-Likert scale ranging from 1 (strongly disagree) to 5 (strongly agree).

This study adopted an analysis technique called the Hierarchical Linear Model (HLM) because it was considered appropriate to test the hypotheses with different levels of analysis variables (crosslevel), the level unit, and individual level (Hofmann, 1998; Hofmann, 1997). Substantively, the HLM is a two-step approach (Hofmann \& Stetzer, 1996). The first step was to examine the differences between the groups for the dependent variable. The second step was to use the intercept parameter generated in the first step, such as a variable level output with a variable group as the antecedent. It was testing the effect known as the intercept-as-outcome model in HLM (random coefficient regression models).

\section{Result}

Table 1 shows the ICC values (1) and ICC (2) for internal marketing, 0.421 and 0.904 , respectively. The agreement index $\left(\mathrm{r}_{\mathrm{wg}}\right)$ has an average value of 0.928 . On the index, the average has exceeded the minimum threshold required equal to o.7. Thus, the conclusion that these results provide support to internal marketing construct justification.

Table 1: Results of Testing Unit Level Data to Construct Internal Marketing

\begin{tabular}{lcccc}
\hline Variable & ICC $(1)$ & ICC $(2)$ & $\mathrm{r}_{\mathrm{wg}}(\mathrm{rat})$ & $\mathrm{r}_{\mathrm{wg}}(\mathrm{med})$ \\
\hline Internal Marketing & 0.421 & 0.904 & 0.928 & 0.943 \\
\hline Note: ICC = interclass correlation coefficient, $\mathrm{r}_{\mathrm{wg}}=$ interrater agreement, rat = average; med = median.
\end{tabular}

Table 2 shows the results of a null model for variable output. The third variable is cognitive moral outcomes, performance behavior and performance results demonstrate the value of chi-square significant cognitive moral $\left(\chi^{2}=34.67857 ; \mathrm{p}<0.01\right)$, performance behavior $\left(\chi^{2}=88.39172 ; \mathrm{p}<0.01\right)$ and performance result $\left(\chi^{2}=149.5375 ; \mathrm{p}<0.01\right)$. These results indicate that there are differences in outcome variables between organisational units. The amount of variance in outcome variables 
between organisational units can be calculated using the ICC. The ICC value shows 5.13 per cent of the variance for the variable cognitive moral, 15.29 per cent of the variance of performance behaviour variables, and 24.43 per cent of the variance in results between organisational units (between unit's variance). There is no minimum requirement (cut-off point) to the ICC index (Woltman, Feldstain, MacKay, \& Rocchi, 2012).

Table 2: Test Result of Null Model

\begin{tabular}{lccc}
\hline Variable & Chi-square $\left(\mathrm{X}^{2}\right)$ & $\sigma^{2}$ dan $\tau$ & ICC $=\tau /\left(\tau+\sigma^{2}\right)$ \\
\hline Cognitive Moral & $\begin{array}{c}\mathrm{X}^{2}(13)=34.67857 \\
<0,01\end{array}$ & $\begin{array}{c}\sigma^{2}=12.99685 \\
\tau=0.70300\end{array}$ & $5.13 \%$ \\
\hline Performance Behavior & $\begin{array}{c}\mathrm{X}^{2}(13)=88.39172 \\
<0,01\end{array}$ & $\begin{array}{c}\sigma^{2}=5.13462 \\
\tau=0.92704\end{array}$ & $15.29 \%$ \\
\hline Results Performance & $\begin{array}{r}\mathrm{X}^{2}(13)=149.5375 \\
<0,01\end{array}$ & $\begin{array}{c}\sigma^{2}=16.82673 \\
\tau=5.44109\end{array}$ & $24.43 \%$ \\
\hline
\end{tabular}

Table 3: Summary of HLM Output

\begin{tabular}{|c|c|c|c|c|c|c|}
\hline \multirow{2}{*}{ Variable } & \multicolumn{2}{|c|}{$\begin{array}{l}\text { Cognitive } \\
\text { moral (MK) }\end{array}$} & \multicolumn{2}{|c|}{$\begin{array}{c}\text { Performance } \\
\text { behaviour (KP) }\end{array}$} & \multicolumn{2}{|c|}{$\begin{array}{c}\text { Results } \\
\text { Performance (KH) }\end{array}$} \\
\hline & $\Gamma$ & S.E & $\gamma$ & S.E & $\gamma$ & S.E \\
\hline Unit Level & & & & & & \\
\hline $\begin{array}{l}\text { Internal marketing } \\
\text { Individual-level }\end{array}$ & $0.236^{*}$ & 0.113 & $0.334^{*}$ & 0.115 & 0.175 & 0.263 \\
\hline Cognitive moral & & & $0.052^{*}$ & 0.026 & $0.193^{*}$ & 0.054 \\
\hline Performance behaviour & 0102 * & 0054 & $0057^{* * *}$ & 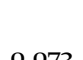 & $0.957^{* *}$ & 0.073 \\
\hline
\end{tabular}

Note: ${ }^{* *} \mathrm{p}<0.01 ;{ }^{*} \mathrm{p}<0.05$

Table 3 illustrates the summary of the hypothesis testing for the effect of internal marketing on behavioural performance, output performance and cognitive moral. The table also gives information about the impact of cognitive moral on behavioural performance and output performance and the influence of behavioural performance on output performance. Regarding the effect of cross-level internal marketing on salespeople performance and cognitive moral, it clearly indicates that internal marketing has a positive effect on behavioural performance $(\gamma=0.334$; SE=0.115; $p<0.05)$ and cognitive moral $(\gamma=0.236$; SE $=0.113 ; \mathrm{p}<0.05)$. Thus, hypotheses 1 and 6 are accepted, while hypothesis 2 is not, that is, internal marketing does not impact salespeople performance. Turning to the hypothesis testing on individuals, it shows that cognitive moral has a positive and significant effect on behavioural performance $(\gamma=0.052 ; \mathrm{SE}=0.026 ; \mathrm{p}<0.05)$ and output performance $(\gamma=0.193$; $\mathrm{SE}=0.054 ; \mathrm{p}<0.05)$. Thus, the hypotheses 3 and 4 are accepted. Hypothesis 5 is accepted in which behavioural performance has a positive effect on output performance $(\gamma=0.957$; SE $=0.073 ; \mathrm{p}<0.01)$.

\section{Discussion}

Based on the analyses and findings in this study, it can be argued that cross-level internal marketing makes an impact on the cognitive moral, behavioural performance, and output performance of salespeople.

It can be argued that cross-level internal marketing is empirically supported, except for the effect of internal marketing on output performance. Internal marketing has a positive and significant effect on salespeople's behavioural performance and cognitive moral. This indicates that internal marketing activities to build a long-term relationship with employees will encourage individuals to develop their individual values. Cognitive moral to high performance by taking into account the 
reward system, internal communication, training and development, and senior management supports to encourage employees to perform better which finally influences business performance (Lenssen, Tyson, Pickard, Bevan, \& Rok, 2009; Papasolomou \& Vrontis, 2006). Individuals (employees) will become more motivated to perform better when deriving much benefit from training and development programs. Their hair needs and desires are well fulfilled, and their senior managers' behaviour supports their work. These findings support the concept of relationship marketing (Christopher, Payne, \& Ballantyne, 2013).

Also, cognitive moral has a positive and significant effect on salespeople's behavioural performance and output performance. This confirms (Schwepker \& Good, 2010) finding. Cognitive moral, which is a decision to either correctly or incorrectly behave, positively affects the business's behavioural performance and output performance to business salespeople. This present finding indicates that an individual's belief about salespeople's right/wrong values and actions positively direct them to to increase their output performance. The following is a more detailed discussion of the present study findings.

\subsection{Effect of Internal Marketing on Salespeople's Performance}

Some studies have examined internal marketing and organisational performance (see, for example, Ali, Rehman, Ali, Yousaf, \& Zia (2010); Parveen, Jaafar, \& Ainin (2015), but the present study, however, differs from previous ones in which this study examines the internal marketing (level units) on salespeople's performance (individual level), namely behavioural performance and salespeople's output performance.

The hypothesis testing results for hypotheses 1 and 2 show that internal marketing has a positive effect on behavioural performance. The second hypothesis indicates that internal marketing fails to affect output performance empirically. In other words, internal marketing that has a positive impact on behavioural performance is empirically proven. This finding is in line with previous findings stating that internal marketing encourages employees to perform better (Joung, Goh, Huffman, Yuan, \& Surles, 2015; Keller et al., 2006; Mazvancheryl et al., 2004).

Individual values are intended to be created by a symbiotic relationship between the company and internal consumers, resulting in improved profitability, customer satisfaction, market share, and organisational efficiency (Kanyurhi \& Akonkwa, 2016; Mazvancheryl et al., 2004). Furthermore, Álvarez-González, García-Rodríguez, Rey-García, \& Sanzo-Perez (2017); Keller et al. (2006) state that internal marketing has a positive effect on internal consumers' performance. When employees feel quality exchanges between them and their organisation, they will achieve better performance in completing their work. Internal marketing has the ability to give the right encouragement to employees to behave better so that they become more focused and responsible for achieving their performance. Employees act more responsibly and become more concentrated on their success achievements when the company satisfies their expectations and aspirations and offers help (Keller et al., 2006; McGrath, 2009).

For Hypothesis 2, it is also found that salespeople's performance is not significantly affected by internal marketing. Internal marketing activities of the best companies in Indonesia do not significantly affect salespeople's output performance. This indicates that internal marketing activities do not encourage and motivate salespeople to improve their output performance. This finding is consistent with Naude et al. (2003), which states that reward satisfaction as an indicator of internal marketing does not significantly affect salespeople's output performance. The income they receive from their company does not meet their needs, that they look for other alternatives to meet their needs by way of additional revenues expected from the achievement of their work. This argument is supported by Carr \& Nanni Jr. (2009); Young \& Flanagan-Cato (2012), who state that the rewards system is not always rational. Still, they are always effective in encouraging individual effort to perform. Employees will make every effort according to their abilities, according to the regulations of their organisations, to maximise the rewards to be obtained. Thus, if the reward system is not 
correctly sent or not adjusted to its strategy, it leads to dysfunctional behaviours. Employees can easily forget about their performance when large private profits will be at stake. Although the reward systems policy cannot provide good results, the reward system can speed up the process if appropriately implemented.

Their performance achievements are more determined by their needs and desires, considering that internal marketing is a process and an attempt to meet customers' needs and desires that each member is treated well as customers and suppliers to the company (Lings, 2004). This is achieved by implementing marketing techniques with a focus on the satisfaction of employees' needs (Foreman \& Money, 1995). This study shows that the internal marketing indicator, such as the strategy of reward designed to motivate employees to achieve their performance, has no significant effect on the salespeople's output performance in the best companies in Indonesia. In other words, the reward strategies as one indicator of internal marketing cannot meet the employees' needs and desires, so that a long-term relationship between the organisation and its employees to reach the organisation's objective is not well developed. Another indicator of internal marketing emphasises on the importance of training for salespeople according to their needs to develop their knowledge and abilities to perform well. Therefore, an investment in training programs is an important component in ensuring that employees always anticipate environmental challenges and make the most possibilities as alternative opportunities and organisation challenges. This is in line with what was stated by Dhar (2015); Foreman \& Money (1995) that resources development is an organisation's strategic investment in training its employees. If employees are required to perform their duties properly, they must be equipped with the skills and knowledge they need. With well-trained and well-developed employees, an organisation will utilise the potential of its resources in full to improve the salespeople's performance.

The finding supports Vroom's theory of expectancy (1964) that emphasises on result factor rather than on necessity. Individuals will be motivated to do certain things to achieve certain goals if they believe that their actions will achieve individual goals. This expectation is influenced by factors such as availability of resources, appropriate skills to do a certain work, availability of information, and managers' support to finish a work. When the company does not fulfil the employee's needs and desires, they will look for other efforts about achieving their work, such as expected revenue from sales (incentives and bonuses), or they will behave unethically to an external consumer.

Furthermore, Sheth \& Parvatiyar (2002) suggests that a longitudinal research approach be used. It is focused on the idea that relationship marketing, like internal marketing and individual production results, is a time-based process. Internal marketing is a fluid phenomenon that changes over time (Fernández-Olmos \& Ramírez-Alesón, 2017). Therefore, it is important to use research techniques as a longitudinal method that measures changes over time (time series).

\subsection{Effect of Internal Marketing on Cognitive Moral}

The effect of the cross-level internal marketing on cognitive moral empirically supported (Hypothesis 6). This is consistent with the notion that internal marketing as a social process will almost certainly be related to moral development because moral behaviour, in general, is a fundamental element in the social act (Kohlberg \& Kramer, 1969). Indicators of internal marketing (such as the delivery of the vision, the reward system, internal communication, training, and development) impact cognitive moral in sales power business to business. Internal marketing creates an environment where every member of the organisation acts both as employees and customers to create an ethical responsibility and moral decision-making such as salespeople performance from business to business. Internal marketing activities will encourage cognitive moral salespeople to consider their moral decision making ethical and responsible.

Internal marketing is a partnership promotional strategy that should be addressed to build a long-term relationship with internal customers (Berry, 2002). Internal marketing as a process of exchange relationships long term between employees and the organisation aims to create a behaviour 
that has the moral values of individual performance behaviour taking into consideration the award, training, and development, and internal communications, as well as supported by a senior leadership role in encouraging employees to perform better. The results of this study found changes in the moral values and attitudes of an individual within the organisation to behave and perform better establish the company legitimacy, for example, the training and development of employees are directed to improve and develop cognitive moral eyes, achieving the desired goals of individuals or organisations, knowledge, abilities, job competence, efficiency, discipline, attitude, and work authorship are examples. Employees will be able to function, strengthen, and develop cognitive moral through training and development.

\subsection{Effect of Cognitive Moral on Salespeople's Performance}

The cognitive moral on salespeople in $\mathrm{B}_{2} \mathrm{~B}$ Indonesian best companies encourage their behaviour to achieve performance. The individual moral considerations will determine the salespeople's performance behaviour in decision-making. This finding is consistent with the opinion of Hunt \& Vitell (2006), who said that the intentions and behaviour of individual performance behaviour would be determined by moral considerations and norms of decision-makers about several relevant environmental issues. Correspondingly, Schwepker \& Good (2010) also say that customer-oriented salespeople's moral considerations positively and significantly affect performance behaviour.

The salespeople's moral level in business-to-business in Indonesia's best company encourages ethical decision-making behaviour. Good behaviour indicates that they perceive higher moral level or their moral judgment. In other words, salespeople in business to business in the best companies in Indonesia would consider moral behaviour and decision-making so that it will produce better organisational performance (Goolsby \& Hunt, 1992). For example, when the decision-making process, the sales performance is influenced by the social environment (such as peers, family, and community) to make good decisions and that individuals will behave better to achieve performance. Furthermore, employees identify correct and incorrect actions driven by hopes to help others. This is consistent with the opinion of Han, Hwang, \& Lee (2017) that the choice of the consumer in the theories of marketing is determined by the intention of behaviour as a precedent cognitive moral, ethical considerations such as cognitive moral may affect intentions behaviour that ultimately determines the performance of salespeople behaviour.

The salespeople's role at the forefront of business organisations is the implementation of strategies designed to encourage and support each other long-term relationships with customers (Webster, 1992). Furthermore, Gundlach \& Murphy (1993) say that an increase in the development of a long-term relationship demonstrates the importance of the placement of high ethical behaviour (moral behaviour). Ethical behaviour can help organisations build, maintain, and expand customer relationships-salespeople considerations are the key to generating ethical decisions such as performance behaviour. The salespeople's moral values serve as the basis for making ethical behaviour decisions to the customer. Therefore, ethical behaviour resulting from moral judgment will lead to increased salespeople performance behaviour.

In addition, the cognitive moral influences positively and significantly on salespeople's results performance in $\mathrm{B} 2 \mathrm{~B}$ (Hypothesis 4). This finding suggests that through the cognitive moral considerations the salespeople will bring the results of their performance. Although salespeople have control over their activities in producing the results obtained, the size of their result is an immediate performance related to the results of the salespeople. This is typically done by adjusting the overall results of their total volume of sales, the creation of market share, sales targets that cannot be controlled by the salespeople (Cravens et al., 1993).

\subsection{Effect of Behavioural Performance on Salespeople's Output Performance}

Performance behaviour has a significant positive effect on the salespeople result performance. The 
findings in this study support the research conducted by previous researchers, like Cravens et al. (1993); Jaworski \& Kohli (1991), stating that salespeople performance behaviour is an important dimension that directly relates to the sales results performance. Sales power usually spend a lot of time in activities and behaviours directly related to the sales results (Cravens et al., 1993), such as convincing customers and understanding customers and customer presentations. Individuals who have good behaviour will create long-term relationships with consumers to improve the results performance and the achievement of their sales volume. In this case, Sojka \& Deeter-Schmelz (2008); Vinchur, Schippmann, Switzer \& Roth (1998) say that the subjective measures of job performance have significantly affected sales performance. Mazvancheryl et al. (2004) argued that affective and cognitive components are important to consider in predicting the behaviour that will ultimately impact the results performance, such as salespeople result in performance. Likewise, Carr \& Nanni (2009) found that affective and cognitive (behavioural) components influence the individual salespeople's level result in performance.

\section{Conclusion}

The results of this study showed support for the relationship between internal marketing on performance behaviour. The salespeople performance and cognitive moral results-likewise, cognitive moral, performance behaviour, and salespeople's performance result of $\mathrm{B}_{2} \mathrm{~B}$. However, internal marketing does not significantly affect salespeople result performance. This study also showed their support for the empirical effects of internal marketing cross-level in the salespeople result in performance and salespeople cognitive moral. The research model also supports Home Visits HV. Internal marketing as a social process can be ensured that moral development is a fundamental element in social behaviour. These findings contribute empirical evidence in the concept of relationship marketing and the theory of marketing ethics.

However, this study indeed has some limitations. The samples of this study were $\mathrm{B}_{2} \mathrm{~B}$ employees in business organisations, both service companies and manufacturing companies; thus the generalisation of research results is limited to these companies. This study's results cannot be generalised to government organisations or business organisations with business employees to consumers. In addition, the data were collected using a self-report questionnaire. This instrument has a weakness in the vulnerability of the social desirability bias (SDB). The indication of the SDB in this study was not tested. Thus, in future studies, it is necessary to carried out a test to get better research results.

This study adopted a survey perspective with a cross-sectional analysis. The respondents filled out various statements and/or questions in the questionnaire. However, this method does not assume that the variables, dependent and independent, have a causal relationship. A cross-section surveys' weakness also lies in the tendency for common method bias. Future research should take into account other approaches for data analysis, such as experimental or longitudinal methods. Furthermore, Sheth \& Parvatiyar (2002) suggest using longitudinal research methods for similar research. This, focused on the premise that relationship marketing, including internal marketing and individual success, is a time-focused operation. Internal marketing is an evolutionary phenomenon and dynamic over time. Therefore, it is important to use research techniques such as longitudinal methods that measure changes over time and time series.

\section{References}

Aceleanu, Mirela Ionela, Molănescu, Anca Gabriela, Crăciun, Liliana, \& Voicu, Cristina. (2015). The status of Romanian agriculture and some measures to take. 22(2).

Ahmed, P K, M.Rafiq, \& NMSaad. (2003). Internal marketing and the mediating role of sorganisational competencies. European Journal of Marketing, 37, 1221-1241. 
Ali, Imran, Rehman, Kashif Ur, Ali, Syed Irshad, Yousaf, Jamil, \& Zia, Maria. (2010). Corporate social responsibility influences, employee commitment and sorganisational performance. 4(13), 2796-2801.

Álvarez-González, Luis Ignacio, García-Rodríguez, Nuria, Rey-García, Marta, \& Sanzo-Perez, María José. (2017). Business-nonprofit partnerships as a driver of internal marketing in nonprofit organizations. Consequences for nonprofit performance and moderators. 20(2), 112-123.

Austin, James T, \& Villanova, Peter. (1992). The criterion problem: 1917-1992. Journal of Applied Psychology, 77, 836-874. doi:10.1037/0021-9010.77.6.836

Behrman, D N, \& P Jr, William D. (1982). Measuring the Performance of Industrial Salespeople. Journal of Business Research, 10, 355-369.

Bennett, Roger, \& Barkensjo, Anna. (2005). Internal Marketing, Negative Experiences, and Volunteers'Commitment to Providing High-Quality Services in a UK Helping and Caring Charitable Organization. VOLUNTAS: International Journal of Voluntary and Nonprofit Organisations, 16, $251-274$. doi:10.1007/s11266-005-7724-o

Berry, L L. (1981). The Employee as Customer. Journal Retail Banking, 3, 25-28.

Berry, L L. (2002). Relationship Marketing of Services Perspectives from 1983 and 2ooo. Journal of Relationship Marketing, 1, 59-77. doi:10.1300/j366vo1no1_05

Bouranta, N, Mavridoglou, G, \& Kyriazopoulos, P. (2005). The impact of Internal Marketing to Market Orientation concept and their effects to bank performance. Operational Research, 5, 349-362. doi:10.1007/bfo2944318

Bowen, D E, \& Lawler, E E. (1992). empowerment of service workers and what, why, how and when. Sloan Management Review, 33, 31-39.

Carr, L. P., \& Nanni Jr, A. J. (2009). Delivering results: Managing what matters.

Caruana, A, \& PCalleya. (1998). The effect of internal marketing on sorganisational commitment among retail bank managers. International Journal of Bank Marketing, 16, 108-116.

Chi, H K, Yeh, H.R, \& Chiou, C.Y. (2008). The Mediating Effects of Internal Marketing on Transformational Leadership and Job Performance of Insurance Salespersons in Taiwan. The Business Review.

Christopher, Martin, Payne, Adrian, \& Ballantyne, David. (2013). Relationship marketing: Taylor \& Francis.

Collins, Brett, \& Payne, Adrian. (1991). Internal marketing: A new perspective for HRM. European Management Journal, 9, 261-270. doi:10.1016/0263-2373(91)90oo6-c

Cravens, DW, N, Ingram T, LaForge, RW, \& Clifford, E. (1993). Behavior-Based and Outcome-Based Salesforce Control Systems. The Journal of Marketing, 57, 47-59.

Dhar, Rajib Lochan. (2015). Service quality and the training of employees: The mediating role of sorganisational commitment. 46, 419-430.

El Fawal, M A, Berg, G A, Wheatley, D J, \& Harland, W A. (1987). Sudden coronary death in Glasgow: nature and frequency of acute coronary lesions. British heart journal, 57, 329-335. doi:10.1136/hrt.57.4.329

Ewing, MTand ACaruana. (1999). An internal marketing approach to public sector management The marketing and human resources interface. The International Journal of Public Sector Management, 12, 17-26.

Fernández-Olmos, Marta, \& Ramírez-Alesón, Marisa. (2017). How internal and external factors influence the dynamics of SME technology collaboration networks over time. 64, 16-27.

Foreman, Susan K, \& Money, Arthur H. (1995). Internal marketing: Concepts, measurement and application. Journal of Marketing Management, 11, 755-768. doi:10.1080/0267257x.1995.9964388

George, William R. (1990). Internal marketing and sorganisational behavior: A partnership in developing customer-conscious employees at every level. Journal of Business Research, 20, 63-70. doi:10.1016/01482963(90)90043-d

Gomez-Mejia, L R, Balkin, D B, \& Cardy, R L. (2007). Managing Human Resources”.

Goolsby, Jerry R, \& Hunt, Shelby D. (1992). Cognitive Moral Development and Marketing. Journal of Marketing, 56, 55. doi:10.2307/1252132

Gronroos, C. (1996). Relationship Marketing: Strategic and Tactical Implications. Management Decision, 34, 5-14.

Gummesson, Evert. (1987). The new marketing-Developing long-term interactive relationships. Long Range Planning, 20, 10-20. doi:10.1016/0024-6301(87)90151-8

Gundlach, Gregory T, \& Murphy, Patrick E. (1993). Ethical and Legal Foundations of Relational Marketing Exchanges. Journal of Marketing, 57, 35. doi:10.2307/1252217

Ha, N C, R.A.Bakar, \& Jaafar, S I S. (2007). Internal Marketing Issues in Service sOrganisations in Malaysia”. International Review of Business Research Papers, 3, 134-145.

Han, Heesup, Hwang, Jinsoo, \& Lee, Sanghyeop. (2017). Cognitive, affective, normative, and moral triggers of sustainable intentions among convention-goers. 51, 1-13.

Hofmann, D. (1998). Centering Decisions in Hierarchical Linear Models: Implications for Research in Organisations. Journal of Management, 24, 623-641. doi:10.1016/s0149-2063(99)80077-4 
Hofmann, David A. (1997). An Overview of the Logic and Rationale of Hierarchical Linear Models. Journal of Management, 23, 723-744. doi:10.1177/014920639702300602

Hofmann, David A, \& Stetzer, Adam. (1996). A Cross-Level Investigation of Factors Influencing Unsafe Behaviors and Accidents. Personnel Psychology, 49, 307-339. doi:10.1111/j.1744-6570.1996.tbo1802.x

Hunt, Shelby D. (2019). The ethics of branding, customer-brand relationships, brand-equity strategy, and branding as a societal institution. 95, 408-416.

Hunt, Shelby D, \& Vitell, Scott J. (2006). The General Theory of Marketing Ethics: A Revision and Three Questions. Journal of Macromarketing, 26, 143-153. doi:10.1177/0276146706290923

Husnain, Mudassir, \& Akhtar, Waheed. (2016). Relationship marketing and customer loyalty: Evidence from banking sector in Pakistan.

Hwang, I S, \& Chi, D.J. (2005). Relationships among Internal Marketing, Employee Job Satisfaction, and International Hotel Performance: An Empirical Study. International Journal of Management, 22, 285.

Iacobucci, D, \& Nordheilm, C. (200o). Creative benchmarking. Harvard Business Review, - , 24-25.

Ishida, Chiharu. (2006). How do Scores of DIT and MJT Differ? A Critical Assessment of the Use of Alternative Moral Development Scales in Studies of Business Ethics. Journal of Business Ethics, 67, 63-74. doi:10.1007/s10551-006-9005-9

Jacobs, Mark A, Yu, Wantao, \& Chavez, Roberto. (2016). The effect of internal communication and employee satisfaction on supply chain integration. 171, 60-70.

Jaworski, Bernard J, \& Kohli, Ajay K. (1991). Supervisory Feedback: Alternative Types and Their Impact on Salespeople's Performance and Satisfaction. Journal of Marketing Research, 28, 190-201. doi:10.1177/002224379102800206

Jones, Jennifer J. (1991). Earnings Management During Import Relief Investigations. Journal of Accounting Research, 29, 193. doi:10.2307/2491047

Jou, J Y H, Chou, C.K., \& Fu, F.L. (2008). Development of an Instrument to Measure Internal Marketing Concept. Journal of Applied Management and Entrepreneurship, 13, 66.

Joung, Hyun-Woo, Goh, Ben K, Huffman, Lynn, Yuan, Jingxue Jessica, \& Surles, James. (2015). Investigating relationships between internal marketing practices and employee sorganisational commitment in the foodservice industry.

Kanyurhi, Eddy Balemba, \& Akonkwa, Déogratias Bugandwa Mungu. (2016). Internal marketing, employee job satisfaction, and perceived sorganisational performance in microfinance institutions.

Keller, Scott B, Lynch, Daniel F, Ellinger, Alexander E, Ozment, John, \& Calantone, Roger. (2006). The Impact of Internal Marketing Efforts in Distribution Service Operations. Journal of Business Logistics, 27, 109-137. doi:10.1002/j.2158-1592.2006.tboo243.x

Kohlberg, L, \& Kramer, R. (1969). Continuities and Discontinuities in Childhood and Adult Moral Development. Human Development, 12, 93-120. doi:10.1159/000270857

Latif, David A. (200o). The link between moral reasoning scores, social desirability, and patient care performance scores: Empirical evidence from the retail pharmacy. Journal of Business Ethics, 25, 255-269. doi:10.1023/a:1006049605298

Lenssen, G, Tyson, S, Pickard, S, Bevan, D, \& Rok, Boleslaw. (2009). Ethical context of the participative leadership model: taking people into account.

Lings, I N. (2004). Internal market orientation: "Construct and consequences". Journal of Business Research, 57, $405-413$.

MacStravic, Robin Scott. (1985). Internal Marketing for Hospitals. Health Marketing Quarterly, 3, 47-54. doi:10.130o/jo26vo3no2_07

Manville, B, \& Ober, J. (2003). Beyond Empowerment: Building a company of citizens. Harvard Business Review, 48-53.

Mazvancheryl, S.K., Anderson, W., \& Fornell, E. (2004). Customer satisfaction and shareholder value. Journal of Marketing, 68, 172-185.

McGrath, P T. (2009). Quantitative mapping of a digenic behavioral trait implicates globin variation in C. Elegans sensory behaviors. Neuron, 61, 692-699.

Miao, C.F., \& Evans, K.R. (2007). The impact of salesperson motivation on role perceptions and job performance a cognitive and affective perspective. Journal of Personal Selling \& Sales Management, 27, 89-101.

Money, A H, \& Foreman, S. (1996). The measurement of internal marketing: a confirmatory case study. Journal of Marketing Management, 11, 755-766.

Morgan, Robert M, \& Hunt, Shelby D. (1994). The Commitment-Trust Theory of Relationship Marketing. Journal of Marketing, 58, 20. doi:10.2307/1252308 
Mossholder, Kevin W, \& Bedeian, Arthur G. (1983). Cross-Level Inference and Organizational Research: Perspectives on Interpretation and Application. Academy of Management Review, 8, $547-558$. doi:10.5465/amr.1983.4284651

Murphy, Patrick E, Laczniak, Gene R, \& Wood, Graham. (2007). An ethical basis for relationship marketing: a virtue ethics perspective. European Journal of Marketing, 41, 37-57. doi:10.1108/03090560710718102

Naude, P, Desai, J, \& Murphy, J. (2003). Identifying the determinants of internal marketing orientation. European Journal of Marketing, 37, 1205.

Neves, Pedro, Almeida, Patrícia, \& Velez, Maria João. (2018). Reducing intentions to resist future change: Combined effects of commitment-based HR practices and ethical leadership. 57(1), 249-261.

Novatorov, E, Kim, S, Wall, K, \& Crompton, J. (1998). The index of recreation marketing excellence: An audit instrument for measuring the effectiveness of marketing efforts at a student recreation center. Journal of Park \& Recreation Administration, 16, 58-80.

Otaye-Ebede, Lilian, Shaffakat, Samah, \& Foster, Scott. (2020). A multilevel model examining the relationships between workplace spirituality, ethical climate and outcomes: A social cognitive theory perspective. 166(3), 611-626.

Paais, Maartje, \& Pattiruhu, Jozef R. (2020). Effect of motivation, leadership, and sorganisational culture on satisfaction and employee performance. $7(8), 577-588$.

Panagopoulos, Nikolaos G, Rapp, Adam A, \& Ogilvie, Jessica L. (2017). Salesperson solution involvement and sales performance: The contingent role of supplier firm and customer-supplier relationship characteristics. 81(4), 144-164.

Panigyrakis, George G, \& Theodoridis, Prokopis K. (2009). Internal marketing impact on business performance in a retail context. International Journal of Retail $\mathcal{E}$ Distribution Management, 37, $600-628$. doi:10.1108/09590550910964620

Papasolomou, Ioanna, \& Vrontis, Demetris. (2006). Building corporate branding through internal marketing: the case of the UK retail bank industry.

Parasuraman, A, Berry, L, \& Zeithmal, V. (1991). Understanding customer expectations of service. Sloan Management Review, 39-48.

Parveen, Farzana, Jaafar, Noor Ismawati, \& Ainin, Sulaiman. (2015). Social media usage and sorganisational performance: Reflections of Malaysian social media managers. 32(1), 67-78.

Reidenbach, R Eric, \& Robin, Donald P. (1988). Some initial steps toward improving the measurement of ethical evaluations of marketing activities. 7(11), 871-879.

Reidenbach, R Eric, Robin, Donald P, \& Dawson, Lyndon. (1991). An application and extension of a multidimensional ethics scale to selected marketing practices and marketing groups. Journal of the Academy of Marketing Science, 19, 83-92. doi:10.1007/bfo272600o

Schwepker, Charles H, \& Good, David J. (2010). Moral Judgment and its Impact on Business-to-Business Sales Performance and Customer Relationships. Journal of Business Ethics, 98, 609-625. doi:10.1007/s10551-010o641-8

Schwepker Jr, C H. (1999). Understanding Salespeople's Intention to Behave Unethically: The Effects of Perceived Competitive Intensity, Cognitive Moral Development and Moral Judgment. Journal of Business Ethics, 21, 303-316.

Selvarajan, Rajan, \& Cloninger, Peggy A. (2009). The influence of job performance outcomes on ethical assessments. Personnel Review, 38, 398-412. doi:10.1108/o0483480910956346

Sherwin, D S. (1983). The ethical roots of the business system. Harvard Business Review, 61, 183-192.

Sheth, J.N, \& Parvatiyar, A. (2002). Evolving Relationship Marketing into a Discipline. Journal of Relationship Marketing, 1, 3-16.

Shiu, Y M, \& Yu, T W. (2010). Internal marketing, sorganisational culture, job satisfaction, and sorganisational performance in non-life insurance. The Service Industries Journal, 30, 793-809.

Sojka, Jane Z, \& Deeter-Schmelz, Dawn R. (2008). Need for Cognition and Affective Orientation as Predictors of Sales Performance: An Investigation of Main and Interaction Effects. Journal of Business and Psychology, 22, 179-19o. doi:10.1007/s10869-008-9069-X

Sujan, Harish, Weitz, Barton A, \& Kumar, Nirmalya. (1994). Learning Orientation, Working Smart, and Effective Selling. Journal of Marketing, 58, 39. doi:10.2307/1252309

Tran, Van Dat, Vo, Thi Ngoc Linh, \& Dinh, Thu Quynh. (2020). The relationship between brand authenticity, brand equity and customer satisfaction. $7(4), 213-221$.

Van Bruggen, Gerrit H, Lilien, Gary L, \& Kacker, Manish. (2002). Informants in Organizational Marketing Research: Why Use Multiple Informants and how to Aggregate Responses. Journal of Marketing Research, 39, 469-478. doi:10.1509/jmkr.39.4.469.19117 
Varela, Otmar E, \& Landis, Ronald S. (2010). A General Structure of Job Performance: Evidence from Two Studies. Journal of Business and Psychology, 25, 625-638. doi:10.1007/s10869-010-9155-8

Varey, Richard J. (1995). Internal marketing: a review and some interdisciplinary research challenges. International Journal of Service Industry Management, 6, 40-63. doi:10.1108/o9564239510078849

Vasconcelos, A F. (2008). Broadening, even more, the internal marketing concept. European Journal of Marketing, 42, $1246-1264$.

Vinchur, Andrew J, Schippmann, Jeffery S, Switzer III, Fred S, \& Roth, Philip L. (1998). A meta-analytic review of predictors of job performance for salespeople. Journal of Applied Psychology, 83, 586-597. doi:10.1037/oo21$9010.83 \cdot 4 \cdot 586$

Vroom, Victor H. (1964). Work and motivation. Wiley.

Wall, Toby D, Michie, Jonathan, Patterson, Malcolm, Wood, Stephen J, Sheehan, Maura, Clegg, Chris W, \& West, Michael. (2004). On The Validity of Subjective Measures of Company Performance. Personnel Psychology, 57, 95-118. doi:10.1111/j.1744-6570.2004.tbo2485.x

Webster, Frederick E. (1992). The Changing Role of Marketing in the Corporation. Journal of Marketing, 56, 1-17. doi:10.1177/002224299205600402

Winter, J P. (1985). Getting your house in order with internal marketing: a marketing prerequisite. Health Marketing Quarterly, 3, 69-77.

Woltman, Heather, Feldstain, Andrea, MacKay, J Christine, \& Rocchi, Meredith. (2012). An introduction to hierarchical linear modeling. Tutorials in Quantitative Methods for Psychology, 8, 52-69. doi:10.20982/tqmp.o8.1.po52

Young, Larry J, \& Flanagan-Cato, Loretta M. (2012). Editorial comment: oxytocin, vasopressin and social behavior. Hormones and behavior, 61, 227-229. doi:10.1016/j.yhbeh.2012.02.019

Zahari, Abdul Rahman, Esa, Elinda, Rajadurai, Jegatheesan, Azizan, Noor Azlinna, \& Muhamad Tamyez, Puteri Fadzline. (2020). The effect of corporate social responsibility practices on brand equity: An examination of malaysia's top 100 brands. 7(2), 271-28o.

Zaman, K, Javaid, N, Arshad, A., \& Bibi, S. (2012). Impact of Internal Marketing on Market Orientation and Business Performance. International Journal of Business and Social Science, 12, 76. 